\title{
Realgar quantum dots induce apoptosis and necrosis in HepG2 cells through endoplasmic reticulum stress
}

\author{
YU QIN ${ }^{1}$, HUAN WANG ${ }^{2}$, ZHENG-YUN LIU ${ }^{1}$, JIE LIU $^{1}$ and JIN-ZHU WU ${ }^{3}$ \\ ${ }^{1}$ Key Laboratory for Basic Pharmacology of Ministry of Education, ${ }^{2}$ The Research Center for Medicine and Biology, \\ Zunyi Medical College, Zunyi, Guizhou 563003; ${ }^{3}$ Department of Chemistry, School of Science, \\ Harbin Institute of Technology, Harbin, Heilongjiang 150001, P.R. China
}

Received April 9, 2015; Accepted June 16, 2015

DOI: $10.3892 /$ br.2015.489

\begin{abstract}
Realgar $\left(\mathrm{As}_{4} \mathrm{~S}_{4}\right)$ has been used in traditional Chinese medicines for treatment of malignancies. However, the poor water solubility of realgar limits its clinical application. To overcome this problem, realgar quantum dots (RQDs; $5.48 \pm 1.09 \mathrm{~nm}$ ) were prepared by a photoluminescence method. The mean particle size was characterized by high-resolution transmission electron microscopy and scanning electron microscopy. Our recent studies revealed that the RQDs were effective against tumor growth in tumor-bearing mice without producing apparent toxicity. The present study investigated their anticancer effects and mechanisms in human hepatocellular carcinoma (HepG2) cells. The HepG2 cells and human normal liver (L02) cells were used to determine the cytotoxicity of RQDs. The portion of apoptotic and dead cells were measured by flow cytometry with Annexin V-fluorescein isothiocyanate/propidium iodide double staining. Apoptosis-related proteins and genes were examined by western blot analysis and reverse transcription-quantitative polymerase chain reaction, and the mitochondrial membrane potential was assayed by confocal microscope with JC-1 as a probe. RQDs exhibited cytotoxicity in a concentration-dependent manner and HepG2 cells were more sensitive compared with normal L02 cells. At $15 \mu \mathrm{g} / \mathrm{ml}, 20 \%$ of the cells were apoptotic, while $60 \%$ of the cells were necrotic at $30 \mu \mathrm{g} / \mathrm{ml}$. The anti-apoptosis protein Bcl-2 was dose-dependently decreased, while pro-apoptotic protein Bax was increased. There was a loss of mitochondrial
\end{abstract}

Correspondence to: Dr Jie Liu, Key Laboratory for Basic Pharmacology of Ministry of Education, Zunyi Medical College, 201 Dalian Road, Zunyi, Guizhou 563003, P.R. China

E-mail: jie@liuonline.com

Dr Jin-Zhu Wu, Department of Chemistry, School of Science, Harbin Institute of Technology, 92 West DaZhi Street, Harbin, Heilongjiang 150001, P.R. China

E-mail: wujinzhu@hit.edu.cn

Key words: realgar quantum dots, HepG2 cells, apoptosis, necrosis, endoplasmic reticulum stress, Bax/Bcl-2 membrane potential and expression of the stress genes C/EBP-homologous protein 10 and glucose-regulated protein 78 was increased by RQDs. RQDs were effective in the inhibition of HepG2 cell proliferation and this effect was due to induction of apoptosis and necrosis through endoplasmic reticulum stress.

\section{Introduction}

The use of arsenic in China can be traced back thousands of years. Arsenic and arsenic salts, including orpiment, realgar and arsenolite, were fundamental ingredients in certain cancer treatments (1). The Fowler's solution (1\% potassium arsenite) was used in the treatment of malignant diseases, such as leukemia and Hodgkin's disease, by numerous physicians in the 19-20th centuries (1). Arsenic trioxide $\left(\mathrm{As}_{2} \mathrm{O}_{3}\right)$ has emerged as the first-line therapy in the treatment of acute promyelocytic leukemia (APL); however, the toxicity hinders its clinical applications $(2,3)$.

Realgar contains $>90 \%$ arsenic sulfide and is widely used externally and internally in a number of traditional medicine recipes in China (4). For example, realgar in combination with Indigo naturalis and Salvia miltiorrhiza is effective against APL (5), and targets RING-type E3 ligase c-CBL to induce degradation of BCR-Abl in chronic myelogenous leukemia (6). Realgar also enhances the antitumor effects of imatinib (7). Results from multicenter clinical trials using oral realgar formulations plus intravenous $\mathrm{As}_{2} \mathrm{O}_{3}$ against hematological malignancy are promising (8).

However, realgar is insoluble in water, resulting in poor bioavailability. The poor solubility of realgar limits its clinical applications (9) and presents a major challenge in cancer chemotherapy (10). The realgar nanoparticles (11-13) and realgar bioleaching solution (14) are more effective compared to crude realgar in antitumor studies, indicative of smaller sizes of realgar being preferable to achieve a more efficient bioavailability (9). Thus, realgar quantum dots (RQDs; $5.48 \pm 1.09 \mathrm{~nm}$ ) were prepared in our previous study using a modified method (15). The cytotoxic effects in vitro of realgar nanoparticles and RQDs on human ovarian (CI80-13S, OVCAR, OVCAR-3) and cervical (HeLa) cancer cell lines was comparable to $\mathrm{As}_{2} \mathrm{O}_{3}(11,15)$; however, their toxicities towards normal cells were to a smaller extent (15). 
Arsenic compounds have also been investigated for their effects against solid tumors, including hepatocellular carcinoma (HCC), in animal models and in humans $(3,9,16)$. Our recent study investigated the effects of RQDs in animal models and identified that RQDs can effectively inhibit the uterine cervix U14 tumor xenografts in tumor-bearing mice, without producing overt toxicity (17). The present study further investigated the effects of RQDs against human hepatocellular (HepG2) cells, focusing on induction of apoptosis and necrosis through endoplasmic reticulum (ER) stress.

\section{Materials and methods}

Cell lines and culture conditions. The tumor HepG2 cell line and normal L02 cell line (3) were purchased from the Cell Bank of Shanghai Institute of Biological Science, Chinese Academy of Sciences (Shanghai, China). The cells were maintained in Dulbecco's modified Eagle's medium (DMEM) supplemented with $10 \%$ fetal bovine serum (FBS), $100 \mu \mathrm{g} / \mathrm{ml}$ streptomycin and $100 \mathrm{IU} / \mathrm{ml}$ penicillin at $37^{\circ} \mathrm{C}$ in a humidified atmosphere of $5 \% \mathrm{CO}_{2}$. Cells in their exponential growth phase were used.

Materials. High-glucose DMEM, FBS and trypsin were purchased from Gibco Life Technologies (Carlsbad, CA, USA). purchased from Gibco Life Technologies (Carlsbad, CA, USA). The antibodies for $\beta$-actin, Bcl-2 and Bax were purchased from Sigma (St. Louis, MO, USA). Secondary antibodies, goat anti-rabbit immunoglobulin G-horseradish peroxidase (IgG-HRP) (SC-2004) and goat anti-mouse IgG-HRP (SC-2005), were purchased from Santa Cruz Biotechnology, Inc. (Dallas, TX, USA).

Preparation of RQDs. RQDs were prepared by Dr Jin-Zhu Wu from Harbin Institute of Technology (Harbin, China) by modifying a previous method (5), with a size of $5.48 \pm 1.09 \mathrm{~nm}$. A total of $2.0 \mathrm{~g}$ course bulk realgar powder was added into $50 \mathrm{ml}$ ethanolamine under bubbling argon gas and an ultrasonic method was used for dissolving. The supernatant was obtained following centrifugation, heated at $80^{\circ} \mathrm{C}$ for $12 \mathrm{~h}$, and subsequently, citric acid was added until $\mathrm{pH} 8.0 \pm 0.2$ was reached. The determination of the photoluminescence (PL) quantum yield of the synthesized RQDs was estimated by a previous method (15).

\section{3-(4,5-Dimethylthiazol-2-yl)-2,5-diphenyl tetrazolium} bromide (MTT) assay to measure cell proliferation. HepG2 and L02 cells were seeded in 96-well plates at a density of $8 \times 10^{3}$ cells/well and cultured at $37^{\circ} \mathrm{C}$ in an incubator with an atmosphere of $5 \% \mathrm{CO}_{2}$ for $24 \mathrm{~h}$. Cells were subsequently treated with phosphate-buffered saline (PBS, control) or different concentrations of $(7.5,15,30$ and $60 \mu \mathrm{g} / \mathrm{ml})$ RQDs. After $6 \mathrm{~h}, 10 \mu \mathrm{l}$ of MTT solution $(5 \mathrm{mg} / \mathrm{ml}$ was dissolved in PBS) was added and the plate was incubated at $37^{\circ} \mathrm{C}$. Four hours later, $100 \mu \mathrm{l}$ of dimethylsulfoxide was added to each well to dissolve the formazan. The amount of colored formazan metabolite formed was determined by measuring its absorbance at $570 \mathrm{~nm}$ in Microplate Reader (Molecular Devices Inc., Sunnyvale, CA, USA). Experiments were performed in 6 replicates in 96-well flat-bottomed culture plates. The half maximal inhibitory concentration $\left(\mathrm{IC}_{50}\right)$ was calculated using
Table I. Primers used in the reverse transcription-polymerase chain reaction.

\begin{tabular}{ll}
\hline Gene & \multicolumn{1}{c}{ Primer sequences $\left(5^{\prime}-3^{\prime}\right)$} \\
\hline Bax & F: AGAGGATGATTGCCGCCGT \\
& R: CAACCACCCTGGTCTTGGATC \\
Bcl-2 & F: ATGTGTGTGGAGAGCGTCAA \\
& R: ACAGTTCCACAAAGGCATCC \\
GADD153 & F: CCACTCTTGACCCTGCTTCT \\
& R: ACCACTCTGTTCCGTTCC \\
FRP78 & F: TAATGGAACGACAGGCACAC \\
& R: TGAGGGCAGGATTTCAAGAC \\
$\beta$-actin & F: TGACGTGGACATCCGCAAAG \\
& R:CTGGAAGGTGGACAGCGAGG
\end{tabular}

F, forward; R, reverse.

SPSS software, version 17 (SPSS, Inc., Chicago, IL, USA) and visualized via graphic plotting.

Flow cytometric analysis of apoptosis. HepG2 cells were seeded in 6-well plates at a density of $1 \times 10^{6}$ cells/well and cultured at $37^{\circ} \mathrm{C}$ in an incubator with an atmosphere of $5 \%$ $\mathrm{CO}_{2}$ for $24 \mathrm{~h}$. HepG2 cells were treated with PBS (control) or different concentrations $(7.5,15$ and $30 \mu \mathrm{g} / \mathrm{ml})$ of RQDs for $6 \mathrm{~h}$ and were trypsinized and collected by centrifugation at $72 \mathrm{x}$ g for $5 \mathrm{~min}$. Subsequent to washing 3 times with cold PBS ( $0.15 \mathrm{M}, \mathrm{pH} 7.2)$, the precipitates were resuspended in $100 \mu \mathrm{l}$ of binding buffer and stained with $5 \mu \mathrm{l}$ of Annexin V-fluorescein isothiocyanate solution together with $10 \mu \mathrm{l}$ of propidium iodide (PI) solution for $20 \mathrm{~min}$ at room temperature in the dark. To each sample tube, $500 \mu \mathrm{l}$ of $1 \mathrm{X}$ binding buffer was added and the samples were analyzed using the FACSCalibur and CellQuest software (Beckman Coulter, Inc., Fullerton, CA, USA). All the experiments were performed in triplicate.

Western blot analysis. HepG2 cells were seeded in 6-well plates at a density of $1 \times 10^{6}$ cells/well and incubated for $24 \mathrm{~h}$. Cells were treated with PBS (control) or different concentrations $(3.75,7.5,15$ and $30 \mu \mathrm{g} / \mathrm{ml})$ of RQDs for $6 \mathrm{~h}$ at $37^{\circ} \mathrm{C}$. The cells were lysed for $10 \mathrm{~min}$ with lysis buffer (radioimmunoprecipitation assay) containing protease inhibitor phenylmethylsulfonyl fluoride. The extracts were subsequently centrifuged at $800 \mathrm{x} \mathrm{g}$ for $10 \mathrm{~min}$ at $4^{\circ} \mathrm{C}$ to remove debris. Following boiling with loading buffer, protein samples were separated by $12 \%$ SDS-PAGE and were transferred onto polyvinylidene difluoride membranes, which were blocked with $5 \%$ non-fat milk for $2 \mathrm{~h}$. Subsequently, membranes were incubated with the primary antibodies at $4^{\circ} \mathrm{C}$ overnight. Following washing 5 times, the membranes were incubated with the HRP-conjugated secondary antibodies at $37^{\circ} \mathrm{C}$ for $2 \mathrm{~h}$. Western blots were developed with ECL (Bio-Rad, Hercules, CA, USA). Normalization was ensured by $\beta$-actin and each band was quantified using ImageJ software.

Reverse transcription-polymerase chain reaction (RT-PCR). HepG2 cells were seeded in 6-well plates at a density of 
Table II. mRNA expression of apoptosis-related genes following RQD treatment.

\begin{tabular}{lccccc}
\hline & \multicolumn{5}{c}{ Concentration of RQD, $\mu \mathrm{g} / \mathrm{ml}$} \\
\cline { 2 - 6 } Gene & 0 & 3.75 & 7.5 & 15 & 30 \\
\hline Bcl-2 & $2.93 \pm 0.91$ & $1.25 \pm 0.26$ & $1.47 \pm 0.59$ & $1.59 \pm 0.24$ & $0.76 \pm 0.19^{\mathrm{a}}$ \\
Bax & $7.44 \pm 0.72$ & $7.06 \pm 0.80$ & $9.04 \pm 1.17$ & $11.8 \pm 0.34^{\mathrm{a}}$ & $10.6 \pm 0.71^{\mathrm{a}}$ \\
\hline
\end{tabular}

${ }^{a} \mathrm{P}<0.05$ indicates significant difference from the control cells. RQD, realgar quantum dot.

$1 \times 10^{6}$ cells/well and incubated for $24 \mathrm{~h}$. When HepG2 cells were treated with PBS (control) or RQDs (3.75, 7.5, 15 and $30 \mu \mathrm{g} / \mathrm{ml}$ ) for $6 \mathrm{~h}$, the total RNA was isolated using TRIzol reagent (Solarbio Science \& Technology Co., Ltd., Beijing, China). The RT was performed with M-MuLV RT (Takara Bio, Inc. Shiga, Japan) according to the manufacturer's instructions. Amplification was performed on the CFX96 Touch Detection System (Bio-Rad) according to the manufacturer's instructions. The primer sequences are given in Table I. Finally, the $\mathrm{C}_{\mathrm{T}}\left(2^{-\Delta \Delta \mathrm{CT}}\right)$ method was used to calculate the relative concentration of the amplified products.

Confocal microscopy. HepG2 cells $\left(1 \times 10^{5}\right)$ were seeded in 35-mm dishes for $24 \mathrm{~h}$, and were subsequently treated with PBS (control) or $30 \mu \mathrm{g} / \mathrm{ml}$ RQDs for $6 \mathrm{~h}$ at $37^{\circ} \mathrm{C}$. Cells were incubated with 5,5',6,6'-tetrachloro-1,1',3,3'-tetraethylbenzimidazolyl-carbocyanine iodide (JC-1) (Qcbio Science \& Technologies Co., Ltd., Shanghai, China) staining liquid for $20 \mathrm{~min}$ at $37^{\circ} \mathrm{C}$, washed 3 times with JC-1 staining buffer and examined under confocal microscope (Leica, Mannheim, Germany).

Statistical analysis. All the data were analyzed using the SPSS 7.5 software for Windows, Student's version. For all the measurements, one-way analysis of variance followed by Tukey's test was used to assess the statistical significance between groups. $\mathrm{P}<0.05$ was considered to indicate a statistically significant difference.

\section{Results}

Characterization of RQDs. The synthesized RQDs were characterized by ultraviolet (UV)-visible spectrophotometry absorption and PL emission spectra exhibiting classic band-edge emission of QDs. The PL emission peak at $475 \mathrm{~nm}$ is in accordance with blue-cyan fluorescence observed under $365 \mathrm{~nm}$ UV light. The mean diameter of the RQDs was $5.48 \pm 1.09 \mathrm{~nm}$

HepG2 cells are more sensitive when compared with LO2 cells to RQDs cytotoxicity. The MTT method was used to evaluate the inhibitory effects of RQDs on the growth of HepG2 and L02 cells. The results demonstrated that the cytotoxicity of RQDs was dose-dependent in the HepG2 and L02 cells (Fig. 1). The RQDs at 20,40 and $80 \mu \mathrm{g} / \mathrm{ml}$ were also investigated. There was a sharp decline from 20 to $40 \mu \mathrm{g} / \mathrm{ml}$ and no significant difference between 40 and $80 \mu \mathrm{g} / \mathrm{ml}$ (data not shown). The

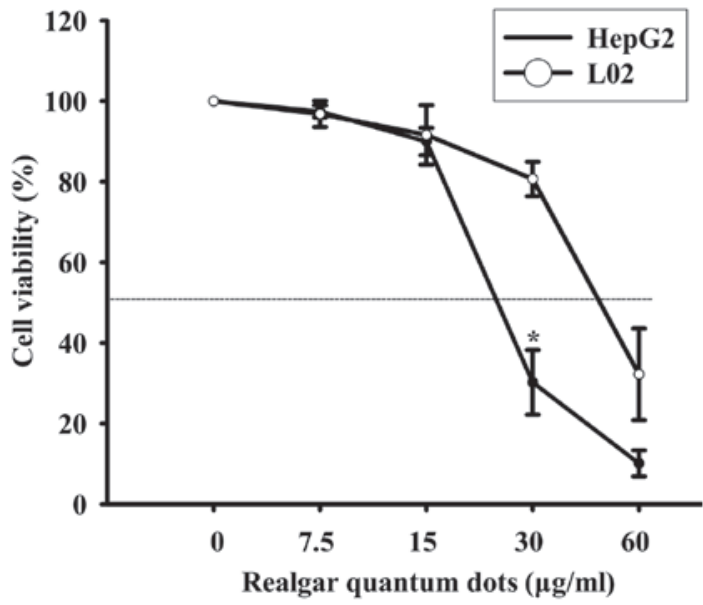

Figure 1. Growth inhibition effects of realgar quantum dots (RQDs) on HepG2 and L02 cells. Cells were treated with phosphate-buffered saline (control) or various concentrations of RQDs for $6 \mathrm{~h}$ and the cell proliferation and survival rates were determined by the MTT assay. The data are expressed as the mean \pm standard deviation of 3 experiments. ${ }^{*} \mathrm{P}<0.05$ indicates a significant difference from the L02 cells.

$\mathrm{IC}_{50}$ for HepG2 and L02 cells after $6 \mathrm{~h}$ were 23 and $50 \mu \mathrm{g} / \mathrm{ml}$, respectively. RQDs exhibited a significantly higher cytotoxicity in HepG2 cells compared with the L02 cells.

$R Q D$ induces apoptosis and necrosis. The apoptotic effect of RQDs on HepG2 cells was detected by flow cytometry with Annexin V/PI staining. The early apoptotic cells were determined by the sum of the cells in D2 and the late apoptosis and necrosis cells appeared mainly in the D4 region (Fig. 2). The percentages of early apoptotic cells following treatment with different RQD concentrations $(0,7.5,15$ and $30 \mu \mathrm{g} / \mathrm{ml})$ were $2.7 \pm 0.3,3.9 \pm 0.3,3.6 \pm 1.1$ and $28.2 \pm 1.8 \%$. The percentages of necrotic and late apoptotic cells were $0.8 \pm 0.1,7.7 \pm 0.5$, $16.1 \pm 0.3$ and $62.6 \pm 2.5 \%$, respectively.

Bax and Bcl-2 protein and mRNA expression. Bax and Bcl-2 are apoptosis-related proteins. The expression of Bax and Bcl-2 was determined in RQD-treated HepG2 cells (Fig. 3). Compared with the control cells, RQDs ( $30 \mu \mathrm{g} / \mathrm{ml})$ induced the downregulated expression of the anti-apoptotic Bcl-2 protein by $50 \%$. By contrast, the expression of the pro-apoptotic Bax protein was upregulated by $36 \%$ following RQD $(3.75,7.5$, 15 and $30 \mu \mathrm{g} / \mathrm{ml}$ ) treatments.

The mRNA expression of the apoptosis-related genes, $B c l-2$ and Bax, was examined (Table II). The mRNA expression of 

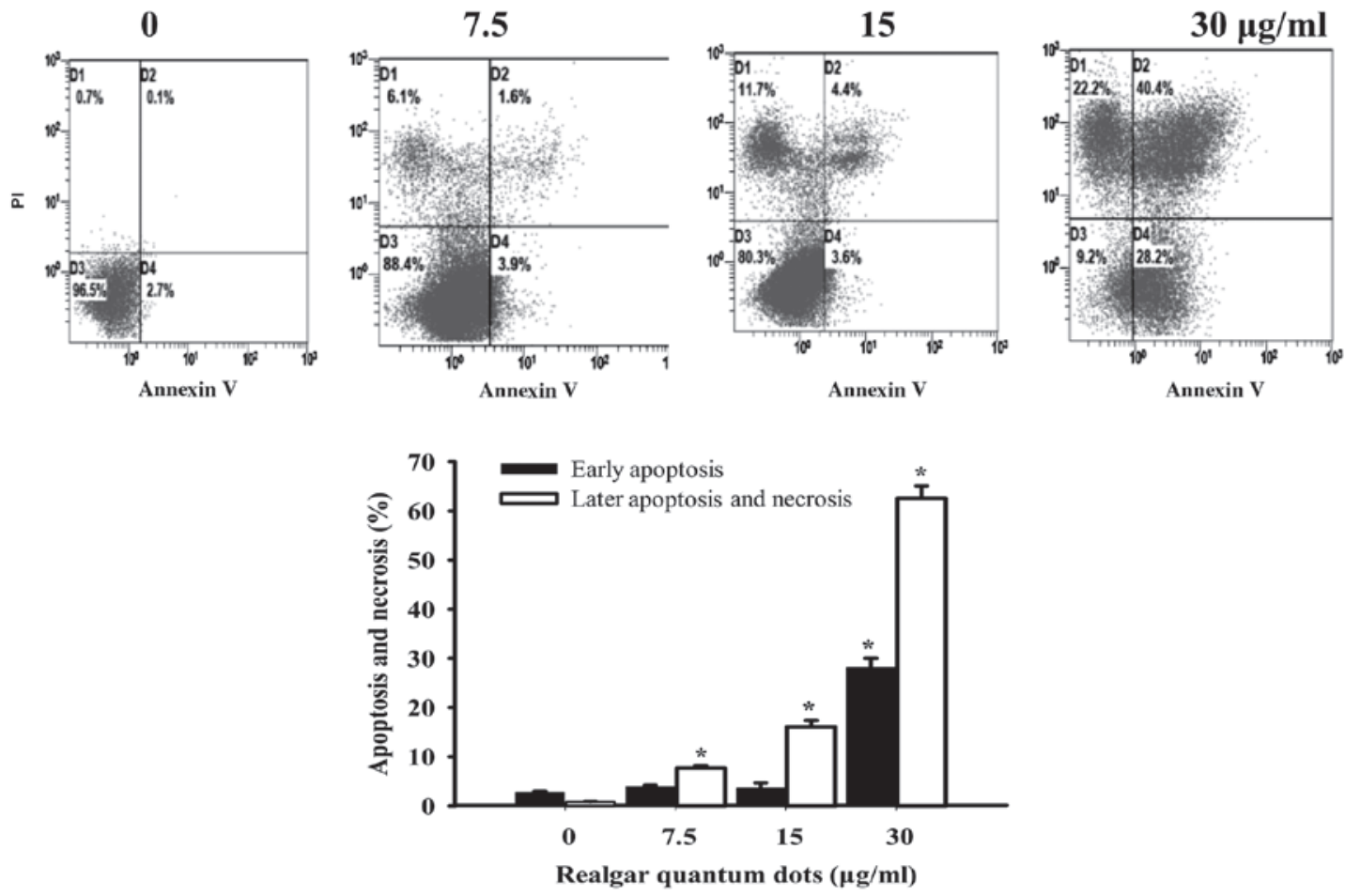

Figure 2. Induction of apoptosis in HepG2 cells by realgar quantum dots (RQDs). Cells were treated with phosphate-buffered saline (control) or various concentrations of RQDs for $6 \mathrm{~h}$ and stained with Annexin V-fluorescein isothiocyanate and propidium iodide (PI). Subsequently, apoptotic and necrotic cells were quantified by flow cytometry. The different subpopulations were defined as D1, Annexin V-negative but PI-positive, i.e. necrotic cells; D2, Annexin V/PI-double positive, i.e. late apoptotic cells; D3, Annexin V/PI-double negative, i.e. normal live cells; and D4, Annexin V-positive but PI-negative, i.e. early apoptotic cells. ${ }^{*} \mathrm{P}<0.05$ indicates a significant difference from the control cells.
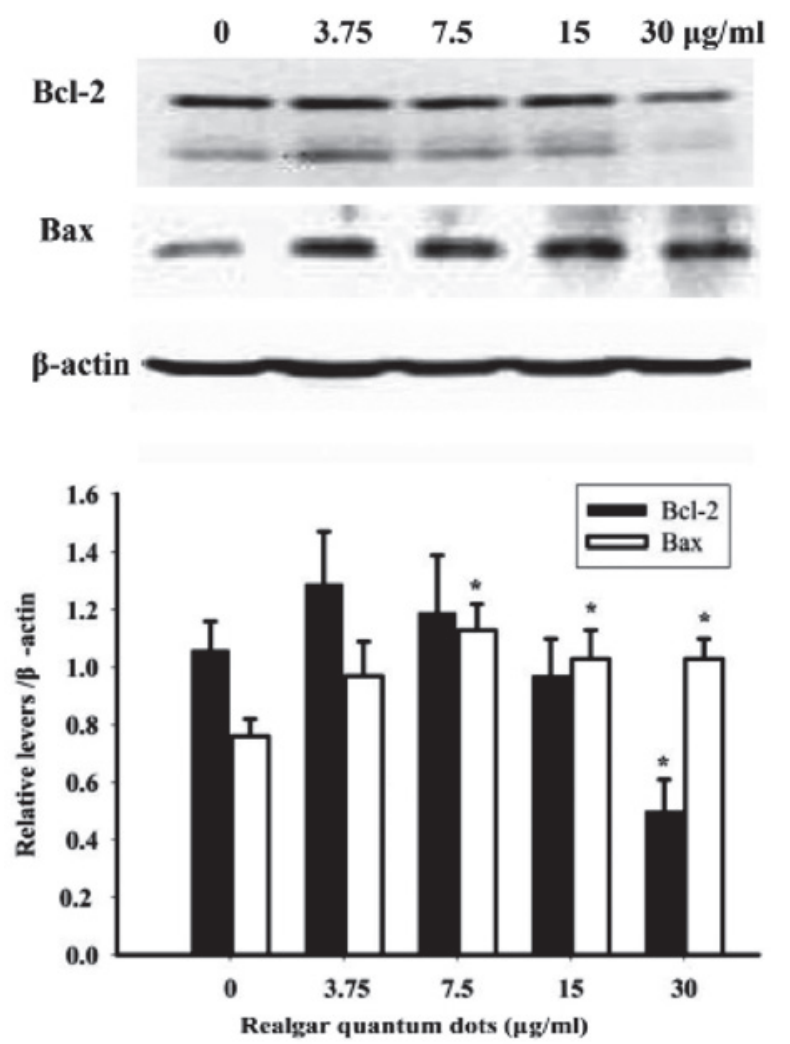

Figure 3. Expression of Bcl-2 and Bax proteins. Cells were treated with phosphate-buffered saline (control) or various concentrations of realgar quantum dots for $6 \mathrm{~h}$ and cellular protein was extracted for analysis of Bcl-2 and Bax expression. Top, representative of western blot analysis; bottom, the quantitative analysis of the relative expression levels in 3-4 replicates. ${ }^{*} \mathrm{P}<0.05$ indicates a significant difference from the control cells.
$B c l-2$ showed a decrease with increasing RQD concentrations, while the mRNA expression of Bax increased by $30 \%$ at $30 \mu \mathrm{g} / \mathrm{ml}$ compared with untreated cells. The mRNA expression of $B c l-2$ and $B a x$ is consistent with their protein levels.

Mitochondrial membrane potential. Mitochondria, as the major energy generators in cells, have a vital role in cell apoptosis induced by stimuli. The JC-1 probe is capable of entering selectively into the mitochondria and reversibly changes its color from red to green as the membrane potential decreases. The results showed that RQDs caused a decrease in the red fluorescence (JC-1 aggregates) and an increase in the green fluorescence (JC-1 monomers), indicative of a loss of mitochondrial membrane potential (Fig. 4).

$m R N A$ expression of ER stress genes. The mRNA expression of ER stress genes, C/EBP-homologous protein 10 (Chop10) (also known as GADD153) and glucose-regulated protein 78 (GRP78) were further examined in RQD-treated HepG2 cells (Fig. 5). The mRNA expression of Chop10 and GRP78 increased with increasing RQD concentrations. Compared with the control group, RQDs $(30 \mu \mathrm{g} / \mathrm{ml})$ induced the expression of Chop10 by 3.14-fold and GRP78 by $\sim 30$-fold.

\section{Discussion}

HCC was reported to be the third most common cause of cancer-related fatality worldwide. The most difficult problem for HCC treatment is the lack of effective chemotherapeutics. Realgar and realgar nanoparticles have been demonstrated to 

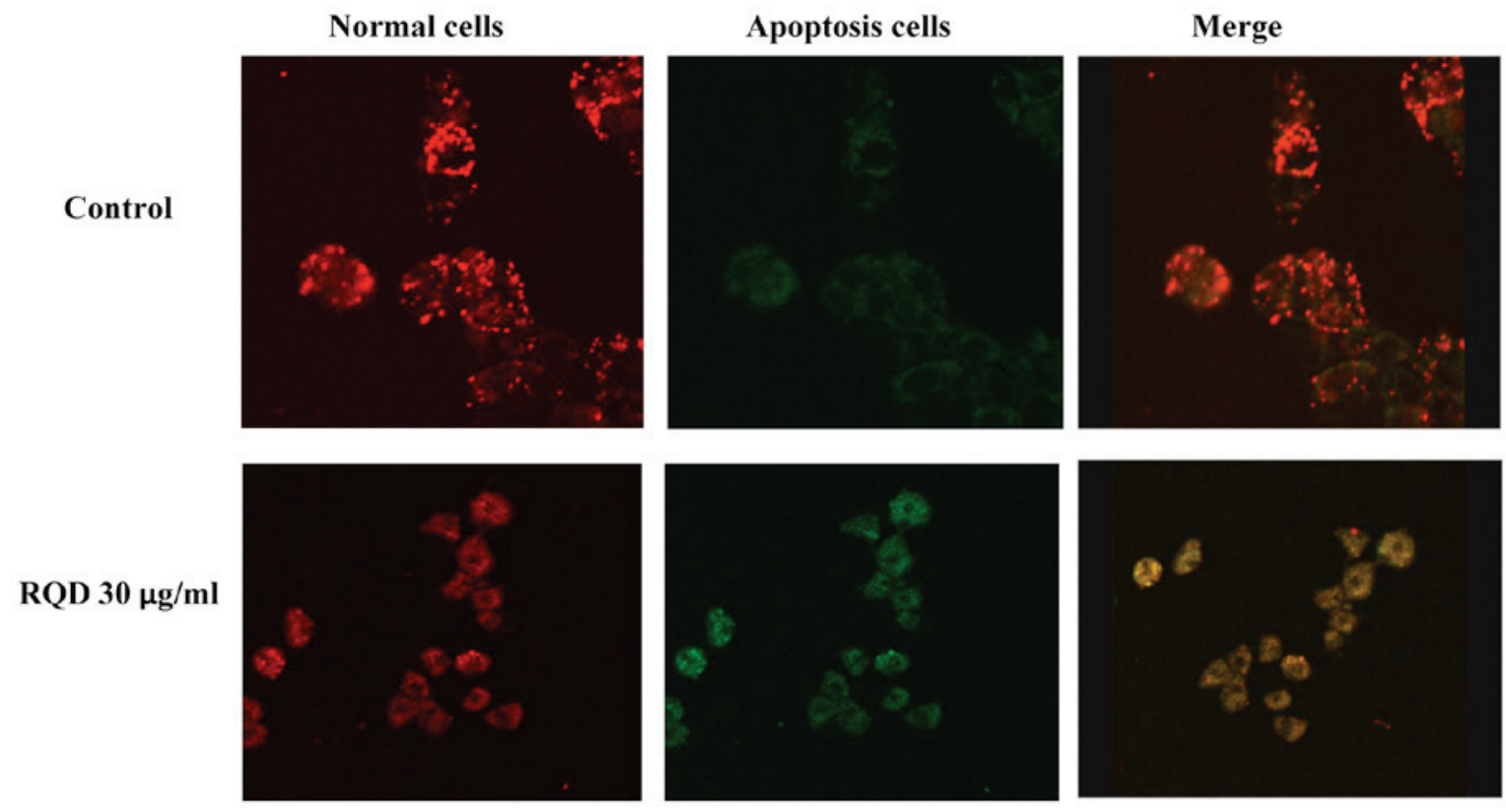

Figure 4. Mitochondrial membrane potential $(\Delta \Psi \mathrm{m})$ analysis using 5,5',6,6'-tetrachloro-1,1',3,3'-tetraethyl benzimidaloyl carbocyanine iodide (JC-1) mitochondrial membrane dye. Cells were treated with phosphate-buffered saline (control) or realgar quantum dots (RQDs) (30 $\mu \mathrm{g} / \mathrm{ml})$ for $6 \mathrm{~h}$. The drug caused an increase in the green (JC-1 monomers) and a decrease in the red fluorescence (JC-1 aggregates), indicative of $\Delta \Psi \mathrm{m}$ loss.

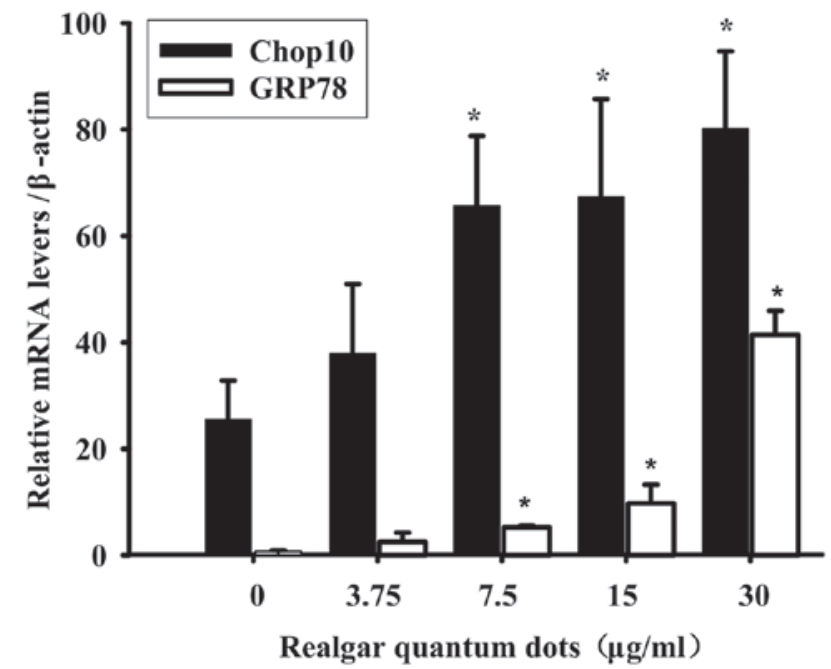

Figure 5. mRNA expression of Chop10 and GRP78. Cells were treated with phosphate-buffered saline (control) or different concentrations of realgar quantum dots for $6 \mathrm{~h}$, and total RNA was extracted for Chop10 and GRP78 expression via reverse transcription-quantitative polymerase chain reaction. Data are mean \pm standard deviation of 3 replicates. ${ }^{~} \mathrm{P}<0.05$ indicates a significant difference from the control cells.

inhibit the proliferation of several cancer cell lines, including hepatocellular HepG2 cells $(3,15)$, and in clinical trials for HCC (2). To improve the bioavailability of realgar through smaller sizes would be an advantageous strategy against solid tumors $(9,10)$. In this regard, RQDs with a size of $\sim 6 \mathrm{~nm}$ were prepared by a chemical method and were revealed to be effective in inhibiting the uterine cervix U14 tumor xenografts without overt toxicity in tumor-bearing mice (17). The present study further demonstrated that it is also effective in inhibiting HepG2 cell growth. At low concentrations (7.5 and $15 \mu \mathrm{g} / \mathrm{ml})$, RQDs induced tumor cell apoptosis and at the high concentration $(30 \mu \mathrm{g} / \mathrm{ml})$ necrosis was induced. The study clearly demonstrates that RQDs are effective against inhibiting proliferation in HepG2 cells.

The MTT assay showed that HepG2 cells were more sensitive when compared to the normal L02 cells for RQD treatments, similar to the differential induction of apoptosis by parthenolide towards HepG2 cells as compared to the normal cells (3), suggestive of HepG2 cell sensitivity to RQDs cytotoxicity.

The results of flow cytometry analysis, as shown in Fig. 2, clearly demonstrated that the percentages of early apoptosis cells increased to $28.2 \%$ and the necrosis cells increased to $62.6 \%$ when treated with $30 \mu \mathrm{g} / \mathrm{ml}$ of RQDs. Dysregulation of apoptosis is linked to the development of the majority of cancers. Thus, induction of apoptosis in cancer cells is a crucial way to induce tumor cell death $(3,18)$. The apoptosis-related protein and gene expression was further examined by western blot analysis and RT-PCR. The results clearly demonstrated that RQDs induced Bax and decreased Bcl-2 expression. The ratio of Bax/Bcl-2 increased $\leq 3$-fold at an RQD dose of $30 \mu \mathrm{g} / \mathrm{ml}$. Dysregulation of apoptosis-related expression of Bax and $\mathrm{Bcl}-2$ is the major mechanism for numerous anticancer agents, such as rice bran phytic acid (19), deoxycholic acid (20) and Saccharina japonica (21), and is a major mechanism for RQDs to induce HepG2 cell death.

The Bcl-2 family is also involved in the regulation and performance of mitochondrial outer membrane permeability, and alteration of the mitochondrial membrane potential leads to cell apoptosis and necrosis. The JC- 1 probe is widely used for mitochondrial membrane potential loss and apoptosis detection (22). The destruction of the mitochondrial membrane potential is a sign of early apoptosis. Apoptotic cells usually have membrane permeability changes. The increase of membrane permeability results in mitochondrial protein release, including cytochrome $c$ and apoptosis-inducing factor 
from the mitochondrial matrix into cytoplasm. The release of cytochrome $c$ with complete loss of membrane potential triggers an apoptosis enzyme cascade effects. The mitochondrial membrane potential decreased significantly when cells were treated with $30 \mu \mathrm{g} / \mathrm{ml}$ RQDs, indicative that the loss of mitochondrial membrane permeability is associated with RQD-induced apoptosis in HepG2 cells.

ER stress is associated with the loss of mitochondrial membrane potential and increased $\mathrm{Bax} / \mathrm{Bcl}-2$ ratio, leading to cell apoptosis $(4,22)$. Targeting ER stress-induced apoptosis and inflammation have become an important strategy in cancer chemotherapy (23). The present study clearly demonstrated that the typical ER stress gene GRP78 increased 30-fold and Chop10 by $>3$-fold in a concentration-dependent manner, indicating that ER stress signaling pathways have an important role in RQD-induced cell death in HepG2 cells.

In conclusion, the present study demonstrated that RQDs are a promising in vitro anticancer agent against human hepatocellular HepG2 cells by inducing apoptosis and necrosis, possibly mediated through ER stress, loss of mitochondrial membrane potential and increase of the $\mathrm{Bax} / \mathrm{Bcl}-2$ ratios leading to hepatocellular cell death.

\section{Acknowledgements}

The present study was supported by the Science and Technology Foundation of Guizhou (grant no. CK-856, 2013-03), the Zunyi Medical Collage, Harbin Institute Postdoctoral Fellowship (grant no. AUGA4110005410), the Fundamental Research Funds for the Central Universities (grant no. HIT IBRSEM 201331) and the Fundamental Research Funds for the Central Universities and Program for Innovation Research of Science in Harbin Institute of Technology (grant no. PIRS of HIT 201411).

\section{References}

1. Liu J, Lu Y, Wu Q, Goyer RA and Waalkes MP: Mineral arsenicals in traditional medicines: Orpiment, realgar and arsenolite. J Pharmacol Exp Ther 326: 363-368, 2008.

2. Hu XM, Liu F and Ma R: Application and assessment of Chinese arsenic drugs in treating malignant hematopathy in China. Chin J Integr Med 16: 368-377, 2010.

3. Ding W, Zhang L, Kim S, Tian W, Tong Y, Liu J, Ma Y and Chen S: Arsenic sulfide as a potential anti cancer drug. Mol Med Rep 11: 968-974, 2015.

4. Liu X, Li X, Wang L, Lv X, Chen N, Li P, Lu K and Wang X: Realgar induces apoptosis in the chronic lymphocytic leukemia cell line MEC 1. Mol Med Rep 8: 1866-1870, 2013.

5. Wang L, Zhou GB, Liu P, Song JH, Liang Y, Yan XJ, Xu F, Wang BS, Mao JH, Shen ZX, et al: Dissection of mechanisms of Chinese medicinal formula Realgar-Indigo naturalis as an effective treatment for promyelocytic leukemia. Proc Natl Acad Sci USA 105: 4826-4831, 2008.

6. Mao JH, Sun XY, Liu JX, Zhang QY, Liu P, Huang QH, Li KK, Chen Q, Chen Z and Chen SJ: As4S4 targets RING-type E3 ligase c-CBL to induce degradation of BCR-ABL in chronic myelogenous leukemia. Proc Natl Acad Sci USA 107: 21683-21688, 2010.
7. Zhang QY, Mao JH, Liu P, Huang QH, Lu J, Xie YY, Weng L, Zhang Y, Chen Q, Chen SJ, et al: A systems biology understanding of the synergistic effects of arsenic sulfide and Imatinib in BCR/ABL-associated leukemia. Proc Natl Acad Sci USA 106: 3378-3383, 2009.

8. Zhu HH, Wu DP, Jin J, Li JY, Ma J, Wang JX, Jiang H, Chen SJ and Huang XJ: Oral tetra-arsenic tetra-sulfide formula versus intravenous arsenic trioxide as first-line treatment of acute promyelocytic leukemia: A multicenter randomized controlled trial. J Clin Oncol 31: 4215-4221, 2013.

9. Wu J, Shao Y, Liu J, Chen G and Ho PC: The medicinal use of realgar $\left(\mathrm{As}_{4} \mathrm{~S}_{4}\right)$ and its recent development as an anticancer agent. J Ethnopharmacol 135: 595-602, 2011.

10. Baláž P and Sedlák J: Arsenic in cancer treatment: Challenges for application of realgar nanoparticles (a minireview). Toxins (Basel) 2: 1568-1581, 2010.

11. Wu JZ and Ho PC: Evaluation of the in vitro activity and in vivo bioavailability of realgar nanoparticles prepared by cryo-grinding. Eur J Pharm Sci 29: 35-44, 2006.

12. Zhao QH, Zhang Y, Liu Y, Wang HL, Shen YY, Yang WJ and Wen LP: Anticancer effect of realgar nanoparticles on mouse melanoma skin cancer in vivo via transdermal drug delivery. Med Oncol 27: 203-212, 2010.

13. Tian Y, Wang X, Xi R, Pan W, Jiang S, Li Z, Zhao Y, Gao G and Liu D: Enhanced antitumor activity of realgar mediated by milling it to nanosize. Int J Nanomedicine 9: 745-757, 2014.

14. Xie QJ, Cao XL, Bai L, Wu ZR, Ma YP and Li HY: Anti-tumor effects and apoptosis induction by Realgar bioleaching solution in Sarcoma-180 cells in vitro and transplanted tumors in mice in vivo. Asian Pac J Cancer Prev 15: 2883-2888, 2014.

15. Wang J, Lin M, Zhang T, Yan Y, Ho PC, Xu QH and Loh KP: Arsenic(II) sulfide quantum dots prepared by a wet process from its bulk. J Am Chem Soc 130: 11596-11597, 2008.

16. Subbarayan PR and Ardalan B: In the war against solid tumors arsenic trioxide needs partners. J Gastrointest Cancer 45: 363-371, 2014.

17. Qin Y, Jing F, Hai J, et al: Anti-tumor effects of realgar quantum dots and Liushen pills in cervical tumor-bearing mice. Chin J N Drugs Clin Remedies 34: 64-67, 2015.

18. Wei S, Cao H, Zhou X, Wu H and Yang J: Prokaryotically and eukaryotically expressed interleukin-24 induces breast cancer growth suppression via activation of apoptosis and inhibition of tumor angiogenesis. Mol Med Rep 11: 3673-3681, 2015.

19. Al-Fatlawi AA, Al-Fatlawi AA, Irshad M,Zafaryab M, Rizvi MM and Ahmad A: Rice bran phytic acid induced apoptosis through regulation of Bcl-2/Bax and p53 genes in HepG2 human hepatocellular carcinoma cells. Asian Pac J Cancer Prev 15: 3731-3736, 2014.

20. Yang HB, Song W, Cheng MD, Fan HF, Gu X, Qiao Y, Lu X, Yu RH and Chen LY: Deoxycholic acid inhibits the growth of BGC-823 gastric carcinoma cells via a p53 mediated pathway. Mol Med Rep 11: 2749-2754, 2015.

21. Il Jung H, Jo MJ, Kim HR, Choi YH and Kim GD: Extract of Saccharina japonica induces apoptosis companied by cell cycle arrest and endoplasmic reticulum stress in SK-Hep1 human hepatocellular carcinoma cells. Asian Pac J Cancer Prev 15: 2993-2999, 2014.

22. Zhang B, Peng X, Li G, Xu Y, Xia X and Wang Q: Oxidative stress is involved in Patulin induced apoptosis in HEK293 cells. Toxicon 94: 1-7, 2015.

23. Verfaillie T, Garg AD and Agostinis P: Targeting ER stress induced apoptosis and inflammation in cancer. Cancer Lett 332: 249-264, 2013. 